die until 1894. It was very appropriate that, when a lectureship was founded in memory of Cayley, Baker was appointed the first holder, in 1903.

Baker quickly threw himself into the work of a college don, and was soon carrying a load of teaching which would make the modern don shudder. He had to teach all the subjects required for the Mathematical Tripos; but in his formal lectures he specialized in the theory of functions and geometry. His principal interest at this time was the theory of algebraic functions, and in spite of his heavy teaching duties he managed to get through a prodigious amount of reading. His first book, "Abel's Theorem and the Allied Theory" (1897), is a monumental work, and his second book, "Multiply Periodic Functions" (1907), is a thorough study of the theory associated with theta functions of two variables. But his papers cover a much wider range-the theory of functions, continuous groups, multiple integrals, projective and algebraic geometry. While a good deal of his original work of this period has been superseded by modern developments, much of permanent value remains, and I recall the pleasure which it gave Baker, only a couple of years ago, to supply reprints of a paper fifty years old which a leading group of American mathematicians was anxious to obtain.

In 1913, Sir Robert Ball, the Lowndean professor who had followed Adams, died, and early in 1914 Baker was elected his successor. The six previous holders of the chair had all been astronomers, and the University statutes of the period did not explicitly allow the Lowndean professor to specialize either in astronomy or in geometry; so Baker, with a characteristic devotion to duty, immediately offered a course on periodic orbits, not in place of, but in addition to, the lectures on the theory of functions which he had been scheduled to give before his election. He kept up his lectures on dynamical astronomy for many years, and a number of distinguished astronomers have spoken of these lectures in the highest terms. But from 1914 onwards he concentrated more and more on geometry, and for some years before he retired his lectures and writings were all on geometry. During his long retirement he continued to work on geometry, and in 1943 he published "An Introduction to Plane Geometry", followed in 1946 by a Cambridge Mathematical Tract, "A locus with 25920 linear selftransformations"; and only two months before his death he completed, in spite of failing eyesight, a commentary on some of his earlier books.

After the First World War, Baker set about building up a school of geometry, and succeeded so well that the 'Baker school' still has its distinetive character. At first the emphasis was primarily on projective geometry, along the lines of von Standt and Reye. To this period we owe the first four volumes of his "Principles of Geometry", which became the bible of his followers. This work reaches its climax in the fourth volume, which deals with the numerous special configurations and loci in four dimensions and their relations with classical configurations such as the double-six in three dimensions, with infectious enthusiasm and many characteristic touches. Later, he lectured more on the birational theory of surfaces, as developed by the Italian geometers, and out of these lectures grew the fifth and sixth volumes of his "Principles". His interest in Italian geometry, however, began much earlier, arising naturally from his work on algebraic functions, and in 1912 he made it the subject of his presidential address to the
London Mathematical Society, perhaps the most influential single article he ever wrote. But what remains most vividly in the minds of all his pupils is the burning enthusiasm he brought to all his teaching, and the enthusiasm he kindled in his audiences. No one ever attended his lectures on geometry without gaining something which remained with him throughout his life. W. V. D. Hodet

\section{Prof. Léon Bertin}

ON February 4, in his sixtieth year, Prof. Léon Bertin was killed in a motor-car accident on the frozen roads outside Paris. He-had held the chair of herpetology and ichthyology at the Muséum National d'Histoire Naturelle since the death of Pellegrin in 1944.

Bertin graduated at the Ecole Normale Supérieure of Paris in 1920 and was awarded a bursary to study for a doctorate. Under Prof. Bouvier he had been initiated, as he said, "au dur métier de la systém. atique" in the field of entomology, and he now took up the study of sticklebacks in a way that would have astonished Mr. Pickwick. Johannes Schmidt had just demonstrated the value of biometry in analysing the races of Zoarces and contrasting their diversity with the homogeneity of the populations of the European eel. Bertin applied like methods to sticklebacks and published on them a series of papers culminating in the classical "Recherches bionomiques, biométriques et systématiques sur les Épinoches (Gasterostéidés)" (1925), which won him his doctorate. The three-spined stickleback shows, in the amount of dermol ossification, a diversity which, expressed in the number of lateral shields, lends itself to numerical analysis. By examining ten thousand specimens from forty-five localities in France and North Africa, Bertin was able to correlate the degree of armature with age, salinity and latitude. Although later work by Heuts has shown that his conclusions were over-simplified, Bertin produced order from chaos and laid a firm foundation on which others have built. The French sticklebacks proved to have a life-span of fourteen to eighteen months. Later, Bertin studied large samples from Iceland and Greenland and demonstrated that these do not become sexually mature until their third or fourth summer, and that they thus conform to the rule of longer life-span in higher latitudes.

This work was followed by studies on bathypelagic eels and then on those enigmatic eel-like fishes, the Lyomeri. Bertin was entrusted with rare and precious material of these groups collected during the cruises of the Dana. As well as a number of smaller papers, he published three Dana Reports on them (the first in collaboration with Roule), and he had work on them in hand at the time of his death.

Throughout his career Bertin was associated with the University of Paris and the Museum. His courses at the University were much appreciated, and that on the eels was published in book form in 1942.

While still 'Sous-Directeur' at the Museum, Bertin organized and directed the indexing of the rich but neglected departmental library of offprints and journals. He appreciated the effect of environment on his staff no less than on the sticklebacks, and visitors to his laboratory in the Jardin des Plantes after the War were impressed by its pleasing decoration and efficient organization as well as by the ready assistance they received. No longer do we read in 
ichthyological papers, "Type in Paris; cannot be found". Under Prof. Bertin the types were found and catalogued. Five fascicles of this catalogue have been published by the Museum, and Unesco funds were to have been made available for the rest.

Bertin developed a talent for popularization. The biggest work of this kind from his hand is "La Vie des Animaux" (1949-50). His contribution to the "Traité de Zoologie" is now in the press and due to appear shortly; so, too, is an English edition of "Les Anguilles".

Bertin served his country as a soldier in both World Wars, and received the Croix de Guerre for courage under bombardment in 1940. A man of distinguished appearance, his personality was dynamic and gay, and it is this that gives a special sadness to his sudden and tragic end. He leaves a widow and three children.

E. Trewavas

\section{Prof. E. D. Merrill}

Elmer Drew Merrill was born on October 15, 1876, in a village near Auburn, Maine; there he grew up amid country sights and sounds. From the village school he passed to a high school in Auburn, walking the three miles in all westhers; and finally to the State College in Orono, which during his years became the University of Maine. He has written that his biological teacher roused his enthusiasm for field work ; but the love of the wilds was already in him: late in life the Maine woods continued to attract him. He was compelled to earn as he learned, serving, for example, as a student-assistant in the botanical laboratory. Having graduated B.S. in 1898, he held a minor appointment until in the next year he was appointed an assistant agrost. ologist in the Dopartment of Agriculture at Washington.

Morrill's excursions in Maine had provided him with a small collection of about a thousand dried plants; and his first entrances into print were records of Maine plants. Three years at Washington led to half a dozen short papers on grasses, along with a valuable training in method. Unexpectedly, he was offered the post of Government botanist in the Philippine Islands. He demurred as untrained for such a responsibility; but it was pressed on him and he arrived in Manila in March 1902, having visited the botanical establishments in Ceylon and Singapore on the way. His beginnings were certainly an adventure : an unfurnished room awaited him. The herbarium of Philippine plants, made by Vidal and nomenclaturally co-ordinated at Kew, had been destroyed in 1897 by an accidental fire; a second herbarium which would have thrown light on the naming in the third edition of Blanco's "Flora" had been destroyed in the fighting of 1899. Such books as there had been, if not burned, had been purloined; and he started from scratch. In twenty-two years his new herbarium grew into a splendid collection of 270,000 mounted sheets and he would have written a descriptive "Flora" had he been left with the opportunities. He had travellod in all parts of tho Archipelago, had had loyal support from forest officers and others interested in plants and had made very effective use of trained Filipino collectors. His office methods were direct and purposeful ; and as no flora can be studied profitably in isolation he had extended his collecting of data to surrounding lands.
This collection was destroyed by the Japanese. It had held the reference material for a vast output of taxonomic papers; but the magnitude of the loss on its destruction is lessened by the existence of duplicates in many herbaria which he, thinking internationally, had distributed abundantly.

As a prelude to the projected Flora of the Archipelago, he published in 1912 a descriptive "Flora of Manila" to support teaching in the University, and to teach was immediately added to his duties. In 1919 a further portion of his time was withdrawn from botanical research, for he was required to take the post of director of the Bureau of Science. His reaction to added work was to lengthen the day; but he could and did turn the projected descriptive "Flora" into an "Enumeration of Philippine Flowering Plants", which appeared during 1923-26, the fourth and last volume holding a masterly phyto. geographical review.

Merrill had married in 1907, and for the sake of the children a home was made in the United States; he spent part of his leave in 1921 with them in California, returning to Manila alone. In 1923 the University of California offered him the appointment of dean of its College of Agriculture. He accepted and served there for five years. Then he was invited to be director of the New York Botanic Garden, and he also served there for five years. In 1935 he was asked to take the post of administrator of the Collections of Harvard University (otherwise director of the Arnold Arboretum), which he held for eleven years. All three posts were difficult by reason of conflicting interests; but he was remarkably successful in all of them. One who knew him intimately wrote of his qualities-quickness of perception, unfailing patience and courtesy, great store of common sense, promptness in taking action, approachableness, and consideration for others. The University of California at Berkeley joked about his early hours used in naming collections that followed him from Manila. His reliability drew unexpectedly large donations towards his projects. In New York during the djstressing slump of 1930 as many unemployed stenographers as he could employ were put at his service, and he used their labour for the innovation of incor. porating descriptions and illustrations among the herbarium sheets. The Harvard University units that wore under his charge were commonly spoken of as the 'orphans'. His first annual report referred to the need of somehow placing them in the 'family'; but re-organization was deferred until after his retirement. His last annual report gives a retrospect of his eleven years and shows the orphans, though still orphans, growing healthily.

In advance of his seventieth birthday Merrill was released on request from administrative duties at the end of the Arboretum's fiscal year (June 30, 1946). He remained Arnold professor of botany and con. tinued his botanical work. The dispersal of cultivated plants had become a major interest. He had criticized in 1920 the extravagant diffusion theories of $\mathrm{O} . \mathrm{F}$. Cook, and later, when at New York, had had occasion. to attack fresh unsubstantial claims of pre-Columbian transfers of useful plants between the Americas and the rest of the world. In 1950 in Washington anthropological friends asked him to sum up the case against new diffusionists, and shortly afterwards one of the diffusionists challenged him to prove his position. In the next year, being in London and at work on plant distribution, it occurred to him that, as the introduction of weeds offers eviderce 